\title{
A Unique Program ("Senso-Math") for Teaching Mathematics in Preschool: Evaluating Facilitator Training
}

\author{
Dina Hassidov1, Bat Sheva Ilany² \\ ${ }^{1}$ Western Galilee College, Akko, Israel \\ ${ }^{2}$ Beit-Berl College, Beit Berl, Israel \\ Email: hasidov@netvision.net.il
}

Received 26 April 2014; revised 20 May 2014; accepted 10 June 2014

Copyright @ 2014 by authors and Scientific Research Publishing Inc.

This work is licensed under the Creative Commons Attribution International License (CC BY). http://creativecommons.org/licenses/by/4.0/

(c) (i) Open Access

\section{Abstract}

This study followed a five-year program, entitled "Senso-Math", whose goal was to train facilitators involved in the promotion of early childhood mathematical knowledge in preschool-an important goal in preschool education today-following which the trained facilitators taught mathematics in preschool alongside the regular preschool teachers. During the program, 500 facilitators activated 10,000 three-to-six-year-old children. The program included various demographic sectors. This study examines both the program's contribution to the professional development of the mathematical education facilitators, and the facilitators' attitudes to mathematical education in the preschool. While the results indicated that, overall, the program contributed positively to the facilitators' professional development and showed a positive trend in the participants' attitude regarding mathematics education in the preschool, the findings also revealed differences among the various demographic sectors studied (Jewish Orthodox, Jewish immigrants from the Caucasus, and Druze).

\section{Keywords}

Facilitators, Mathematics Education, Preschool, Kindergarten, Senso-Math

\section{Introduction and Theoretical Background}

Recent years have seen a change regarding the importance of the learning environment and the teacher's role, with a change from the traditional environment, where the teacher transmits knowledge, to an active and constructivist learning one (Cobb, 1996). This change has led to a transformation in the teacher's role and responsibilities. In this 
new environment, the teacher serves more as a facilitator or mediator who encourages learning by enabling opportunities for the students to engage in interesting activities. The student takes on the responsibility for building their learning experience from the knowledge available.

The global trend today is to favor access to mathematics at a young age. Because, in essence, young children are engaged in mathematics in daily life from birth (Early Childhood Mathematics, NAEYC, 2002), preschool math practice should develop that awareness so as to cultivate mathematical thinking at an early age. In fact, studies have shown that preschool children have the ability to build concrete mathematical, sometimes even abstract, processes, and the earlier that children are exposed to the experience, the greater the child's mathematical development will be later. Indeed, preschool math practice helps in shaping the child's future cognition, mathematical thinking, general thinking, and cognitive abilities (Baroody, 2000). In addition, studies have shown that the volume and quality of math practice during preschool predict a child's success in math in elementary school (Clements \& Sarama, 2006).

Neuroscience research shows that preschool math activity is important. Clements (2001) emphasizes that the structure and organization of the brain of developing preschoolers is affected by their learning experience, and that complex activities lead to increased brain development.

Given the above, it is clear that teaching mathematics to preschoolers requires professional knowledge on the part of mathematics teachers, and teachers are nowadays required to have sufficient knowledge of teaching mathematics in preschool.

It has been shown that teachers' attitudes are one of the main factors affecting children's attitudes towards mathematics (Philippou \& Christou, 1998; Plucker, 1996). The reason is that teachers serve as a model for their students (Charalambous, Panaoura, \& Philippou, 2009; Philipp, 2007). Attitudes are effective structures, stable over time through which people react to certain things in a certain way (McLeod, 1992; Fiske \& Taylor, 2008). When dealing with mathematics, the teachers' attitudes are reflected in the way learners study, feel or think (Charalambous et al., 2009; Philipp, 2007).

Unfortunately, studies conducted in recent years indicate that teachers assigned with teaching mathematics in preschool find themselves facing difficulties and feelings of incapacity for the job. This may, in part, stem from negative personal experiences, but it is also due to a lack of professional knowledge because appropriate training in teaching preschool mathematics was not acquired in college (Tiroshe \& Graeber, 1990; Ben-Yehuda \& Ilany, 2008; Guo, Justice, Sawyer, \& Tompkins, 2011). The result is that teachers lack adequate knowledge to teach mathematics in preschool.

Thus, preschool teachers, in addition to the load of commitment which any preschool teacher must take on, find themselves heavily burdened with the responsibility of creating and enabling positive experiences in foundation mathematics for young learners so as to build in the children readiness for the transition to school—without adequate training.

The conclusion from these (and other) studies was that appropriate assistance programs must be developed to strengthen teachers' sense of competence to teach mathematics in preschool. Such assistance programs should be structured according to the new teaching principles: to develop quantitative, critical and creative understanding, to direct towards thinking and understanding, and to encourage mathematical discourse (Pimm, 1987) and metacognitive processes (NCTM, 2000).

\section{Preschool Learning}

One of Piaget's principles state that toddlers are approaching readiness for formal and abstract learning (Piaget definitions: ages $4-8$, the pre-operational and the operational). In this period, a child's thought structures are constructed, and visual and verbal representations are built. The child's activity at this age is essentially intuitive, combining imitation and imagination. Age restrictions mean that children have subjective vision (considered egocentric) and adhere to sensory impressions. This leads to restrictions in the child's ability to reach generalizations such as conservation and reversibility (Boden, 1999; Vygotsky, 1962).

Nevertheless, studies have indicated that a change can be achieved in a child's foundation for logical understanding through mediation: Developmental psychology emphasizes that such a change can occur in the physicalsocial environment providing that opportunities are given to experience physical objects, speculate, argue, and explain (Kilpatrick, Swafford, \& Findell, 2001). These changes can also occur in the realm of mathematics and mathematical language. In order for it to do so, it is important for a child to solve problems appropriate to his 
unique needs as a learner (Carpenter, Fenemma, Peterson, \& Carey, 1998). In other words, the child must be able to find and apply the relationship between the understanding of mathematics as an abstract knowledge and its relevance to his day-to-day world.

\section{The "Senso-Math" Program}

Based on the understanding that a change was needed in teacher-training methods, and taking into account the unique character of preschool learning, the "Senso-Math" program was developed by D. Hassidov, M. Klugman, and J. Oberman (2004-2005). One of its main goals was to train facilitators to supplement the teaching of mathematics in the preschool. Another goal was to eventually integrate the facilitators into mathematics teaching in preschools or into other areas of education to which they would be able to contribute.

The "Senso-Math" program is based upon the definition of the new curriculum of the Israel Ministry of Education for mathematics in early childhood (2009). It aims to give preschool children the chance to experience math as it occurs in their daily world, by training facilitators to use the children's day-to-day experiences as a basis for learning math concepts. The "Senso-Math" program includes diverse and dynamic graded exercises, and specially developed unique learning materials that combine sensory and motoric activities.

The topics covered are based on the curriculum of the Israel Ministry of Education (2009), which is divided into ten subject areas, each with three learning styles: creative, structured, and daily environment. Thirty teachinglearning sets were thus developed to be used by the facilitators and the preschool teachers during the year. The program aimed to cover three years of schooling (pre-nursery, nursery and kindergarten) and material was divided according to the level of knowledge maturity of the children in the various levels. It is aimed to prepare preschool children for first grade.

The material encourages transcription and reflective mathematical discourse. Children research mathematical problems of daily life using all their senses and internalize mathematical operations and concepts. The children work in small groups that encourage brainstorming and group discussion.

"Senso-Math" teaching kits include specially designed mathematical materials intended to assist the teachers and facilitators in developing mathematical thinking in their early childhood pupils, to allow them to organize a program with a rich mathematical learning environment that would be experiential and authentic, and to combine creativity with the appropriate use of language, according to the individual needs of each child. It also includes information about how children learn and various teaching methods, based on the premise that the program will work better if the concepts behind it are clear to the teacher.

Teaching sets contain assignment cards describing different activities to use in the classes. Assignment cards include the purpose of the activity, number of participants (single, pair or group), level of activity and the recommended accessories, and came with learning and activity materials for the children, teachers, and facilitators. Activities are meant to be flexible and can be adapted and expanded to the subjects at hand.

The child's learning kit (each child receives one) includes material and worksheets for use during the year according to the facilitator's instructions. Some of the child's kit accessories are intended to be sent home for activities involving the parents.

In each preschool, learning groups were assembled according to the recommendation of the teacher. The facilitator worked with the children once or twice a week, either in their formal preschool or in the afternoon, within the framework of enrichment classes, and for a period of 40 minutes each time for ages four to six, and 30 minutes for ages three to four. Activities were held in groups of up to ten children, and included combined motoric activities, movement, knowledge acquisition and experiencing educational materials. The pedagogical and mathematical rational of the "Senso-Math" teaching kits were initially tested in 20 preschools.

The results of the initial program were validated through observation, data collection, and accompanying research, then were revised to further enrich the curriculum framework. After final approval by the Israel Ministry of Education, several hundred preschools were chosen to integrate the program in facilitated preschool mathematical education.

\section{Facilitator Training}

Five hundred women took part in the program. The participating women were academic- and college-educated. We determined suitability for the program through personal interviews and appropriate certification. The participants underwent training in groups of up to 25 participants each, throughout the country. These studies prepared participants for professional teaching and promoting mathematical knowledge in preschoolers. The training 
covered two areas: 40 hours of training focused on integration into the preschool administratively; and 88 hours focused on mathematical education in early childhood and hands-on experimentation and application of the "Senso-Math" program in preschools. They were also taught to coach the preschool teachers in teaching mathematics, by modeling and demonstrating the method.

The participants attended 128 academic hours in over 20 sessions. First-year studies took place four times a week, four academic hours each, over eight weeks. In the second year, participants studied for 28 hours, during which the topics were expanded. Part of the training included practical experience in preschools, during which each facilitator received 15 hours of individual professional guidance at the beginning of her practical work in the class based upon her needs.

Content training included several areas: methods of teaching and learning, mathematical education, and cognitive abilities of preschool children. The "Senso-Math" moderator's kit (see above) was used during the facilitators' training as a center of activity. Facilitators used the same kit in the preschool.

\section{Research Hypotheses}

This study set out to focus on a number of hypotheses regarding the "Senso-Math" program in order to arrive at conclusions as to the worthiness of the program. In particular, we postulated the following:

1) The program increased the participant's motivation to work.

2) The program increases participants' conviction in the necessity of mathematics learning in preschool.

3) The program encourages participants to take a responsible approach to their professional development.

4) The program increases participants' confidence in teaching mathematics.

5) The program gives facilitators appropriate tools and means for preschool mathematics teaching.

6) Participants from different socio-economic groups will show a difference regarding their perception of the training.

\section{Method}

\subsection{Population}

Of the 500 participants in the "Senso-Math" program, 49 were chosen (randomly) to take part in this study. The average education of the study group was 14.5 years of schooling. Each had a suitable diploma or training certificate from a teachers' college or other school of higher education, and were mathematically oriented and with the ability to work as mathematical facilitators in preschool. And although they all had a background in early childhood education, none of the participants had ever worked in preschool education.

The average age was almost 34 years old. The women were of heterogeneous marital status. They came from diverse socio-economic and demographic sectors from around the country and included religious and secular; Jewish and Druze; long-time residents and new immigrants from the Caucasus. The women all came from three major communities: orthodox Jewish from the center of Israel, new immigrants from the Caucasus who live in Haifa, and Druze from Karmiel (see Table 1).

\subsection{Research Tools}

Research methods were both quantitative and qualitative. The data were collected via questionnaires and interviews that had been written by the researchers.

The questionnaire included 22 statements (see below) to ascertain the participants' attitudes to teaching mathematics in preschool and to their "Senso-Math" training program. Fifteen facilitators (who were not included in the study group) validated the questionnaires. The 49 study participants were asked to rate the statements from 1 (a very great extent) to 5 (not at all). Negative statements have been marked.

After filling in the questionnaires, semi-structured interviews were conducted with all the study participants (n $=49$ ) to clarify their approach to the statements on the questionnaire. Relevant background information was also collected at this time, such as age, education, place of residence, occupation and socioeconomic status.

Data collection was performed at three times: at the beginning of this study, at completion of training, and a year after completion of the training.

Statements about attitudes toward learning mathematics: It is important that children start learning mathematics in preschool; Children of preschool age can learn mathematics; If the basics of mathematics are learned 
Table 1. Participants in the "Senso-Math" study training program.

\begin{tabular}{cccc}
\hline & & $\mathbf{N}$ & $\mathbf{\%}$ \\
\hline \multirow{3}{*}{ Marital status } & Married & 38 & 77.6 \\
& Single & 5 & 10.2 \\
& Divorced/ separated & 6 & 12.2 \\
& Total & $\mathbf{4 9}$ & $\mathbf{1 0 0}$ \\
& Haifa area & 15 & 30.6 \\
Program location & Center of Israel (Religious) & 15 & 30.6 \\
& Galilee & 19 & 38.8 \\
\hline Age & Total & $\mathbf{4 9}$ & $\mathbf{1 0 0}$ \\
\hline No of children & Average & Standard deviation & $\mathbf{N}$ \\
Years studied & 33.98 & 8.48 & 49 \\
\hline
\end{tabular}

before first grade, the child will develop a positive attitude towards the subject; Anyone can learn mathematics; I see my future in teaching children mathematics; Anyone can enjoy learning mathematics.

Statements about development of professional confidence: Anyone who aspires to succeed can do it at any age; Unemployed women should be concerned about their professional development; Teaching mathematics in preschool requires readiness, knowledge, and professional maturity; The training encouraged me to start teaching mathematics in preschool; I feel I can incorporate the "Senso-Math" program into the preschool; The training gave me professional confidence; The training encouraged me to pursue my professional aspirations; I am considering making mathematics teaching my main profession.

Statements about self-confidence in teaching mathematics: The training gave me confidence to teach mathematics; Had I not participated in the "Senso-Math" program, I would not have confidence to teach mathematics.

Statements about evaluation of the program: The "Senso-Math" facilitators' kit helped me in mathematical guidance in the preschool; The "Senso-Math" activity pages helped me in mathematical facilitation in the preschool; The course was conducted professionally; The training gave me tools to facilitate mathematics in preschool; The training gave me tools to teach mathematics in preschool; I would recommend participating in the "Senso-Math" program to a friend.

\section{Results}

\subsection{Employment Status at the Beginning of the Study, at the End and a Year Later}

Table 2 shows that at the end of the study, $69 \%$ of the subjects stated that they were working compared with $66 \%$ at the beginning of the study. A year later, 75\% stated that they are working, $9 \%$ of them in "Senso-Math" and the rest in other educational fields.

\subsection{Attitudes toward Teaching Mathematics}

Table 3 shows that the average rating of the statements pertaining to the participants' attitude to teaching mathematics is close to 4 and above. The findings indicate that they thought that that preschool mathematics education was important (average 4.65), that they had developed a positive attitude to the profession (average 4.51), and that they believed that anyone can learn math (average 4.15). As can be seen from Figure 1, the statement that received the highest average score is "It is important that children start learning mathematics in preschool," (average 4.65), while the least important statement is "Anyone can enjoy learning mathematics" (average 3.88).

\subsection{Developing Professional Confidence}

Table 4 indicates that the statement which received the highest average score is "Anyone who aspires to succeed 
Table 2. Employment status at the beginning of study, at the end, and a year later (Hypothesis No. 1).

\begin{tabular}{|c|c|c|c|}
\hline & & No. of respondents & $\%$ \\
\hline \multirow{6}{*}{$\begin{array}{l}\text { Occupational status before entering } \\
\text { the program }\end{array}$} & I worked full time & 14 & 28.6 \\
\hline & I worked part time & 19 & 38.8 \\
\hline & I was unemployed & 6 & 12.2 \\
\hline & I chose not to work (was a housewife) & 6 & 12.2 \\
\hline & I worked at odd jobs & 4 & 8.2 \\
\hline & Total & 49 & 100 \\
\hline \multirow{6}{*}{$\begin{array}{l}\text { Occupational status after completing } \\
\text { the "Senso-Math” training }\end{array}$} & I work full time & 12 & 24.5 \\
\hline & I work part time & 15 & 30.6 \\
\hline & I am unemployed & 8 & 16.3 \\
\hline & I choose not to work (housewife) & 7 & 14.3 \\
\hline & I work at odd jobs & 7 & 14.3 \\
\hline & Total & 49 & 100 \\
\hline \multirow{3}{*}{$\begin{array}{l}\text { Occupational status a year after } \\
\text { completing the training }\end{array}$} & Working & 37 & 75 \\
\hline & Not working & 12 & 25 \\
\hline & Total & 49 & 100 \\
\hline \multirow{3}{*}{$\begin{array}{l}\text { Place of work a year after completing } \\
\text { the training }\end{array}$} & Teaching “Senso-Math” in preschool & 4 & 8.2 \\
\hline & Educational field & 27 & 55.1 \\
\hline & Other & 10 & 20.4 \\
\hline \multirow{7}{*}{$\begin{array}{l}\text { Job extent a year after completing } \\
\text { the training }\end{array}$} & Did not respond & 8 & 16.3 \\
\hline & Total & 49 & 100 \\
\hline & Part-time/temporary & 23 & 46.9 \\
\hline & Full time/almost full time & 16 & 32.7 \\
\hline & Self-employed & 1 & 2.0 \\
\hline & Did not respond) & 9 & 18.4 \\
\hline & Total & 40 & 100 \\
\hline
\end{tabular}

Table 3. Attitudes of participants towards learning mathematics (Hypothesis No. 2).

\begin{tabular}{|c|c|c|c|c|c|c|c|c|c|c|c|}
\hline & \multicolumn{2}{|c|}{ Slightly } & \multicolumn{2}{|c|}{ Moderately } & \multicolumn{2}{|c|}{ To a large extent } & \multicolumn{2}{|c|}{ To a great extent } & \multirow{2}{*}{$\begin{array}{c}\text { Average } \\
\text { AV }\end{array}$} & \multicolumn{2}{|c|}{ Total } \\
\hline & $\mathrm{N}$ & $\%$ & $\mathrm{~N}$ & $\%$ & $\mathrm{~N}$ & $\%$ & $\mathrm{~N}$ & $\%$ & & $\mathrm{~N}$ & $\%$ \\
\hline $\begin{array}{l}\text { Children of preschool age can learn } \\
\text { mathematics. }\end{array}$ & & & 4 & 8.3 & 15 & 31.3 & 29 & 60.4 & 4.52 & 48 & 100 \\
\hline Anyone can learn mathematics. & & & 11 & 23.4 & 18 & 38.3 & 18 & 38.3 & 4.15 & 47 & 100 \\
\hline $\begin{array}{l}\text { If the basics of mathematics } \\
\text { are learned before first grade, the } \\
\text { child will develop a positive } \\
\text { attitude towards the subject. }\end{array}$ & & & 2 & 4.1 & 20 & 40.8 & 27 & 55.1 & 4.51 & 49 & 100 \\
\hline $\begin{array}{l}\text { Anyone can enjoy learning } \\
\text { mathematics. }\end{array}$ & 4 & 8.3 & 14 & 29.2 & 14 & 29.2 & 16 & 33.3 & 3.88 & 48 & 100 \\
\hline $\begin{array}{l}\text { I see my future in teaching children } \\
\text { mathematics. }\end{array}$ & 1 & 2.1 & 13 & 27.1 & 15 & 31.3 & 19 & 39.6 & 4.08 & 48 & 100 \\
\hline $\begin{array}{l}\text { It is important that children start } \\
\text { learning mathematics in preschool. }\end{array}$ & & & 2 & 4.2 & 13 & 27.1 & 33 & 68.8 & 4.65 & 48 & 100 \\
\hline
\end{tabular}


Table 4. Rating of the statements: Development of professional confidence (Hypothesis No. 3).

\begin{tabular}{|c|c|c|c|c|c|c|c|c|c|c|c|c|c|}
\hline & \multicolumn{2}{|c|}{ Not at all } & \multicolumn{2}{|c|}{ Slightly } & \multicolumn{2}{|c|}{ Moderately } & \multicolumn{2}{|c|}{$\begin{array}{l}\text { To a large } \\
\text { extent }\end{array}$} & \multicolumn{2}{|c|}{$\begin{array}{l}\text { To a great } \\
\text { extent }\end{array}$} & \multirow{2}{*}{$\begin{array}{c}\text { Average } \\
\text { AV }\end{array}$} & \multicolumn{2}{|c|}{ Total } \\
\hline & $\mathrm{N}$ & $\%$ & $\mathrm{~N}$ & $\%$ & $\mathrm{~N}$ & $\%$ & $\mathrm{~N}$ & $\%$ & $\mathrm{~N}$ & $\%$ & & $\mathrm{~N}$ & $\%$ \\
\hline $\begin{array}{l}\text { Anyone who aspires to succeed } \\
\text { can do it at any age. }\end{array}$ & 1 & 2.0 & 1 & 2.0 & 9 & 18.4 & 18 & 36.7 & 20 & 40.8 & 4.40 & 49 & 100 \\
\hline $\begin{array}{l}\text { Unemployed women should be } \\
\text { concerned about their professional } \\
\text { development. }\end{array}$ & 16 & 32.7 & 10 & 20.4 & 10 & 20.4 & 11 & 22.4 & 2 & 4.1 & 4.12 & 49 & 100 \\
\hline $\begin{array}{l}\text { Teaching mathematics in preschool } \\
\text { requires readiness, knowledge, and } \\
\text { professional maturity. }\end{array}$ & 7 & 14.6 & 11 & 22.9 & 13 & 27.1 & 11 & 22.9 & 6 & 12.5 & 3.79 & 48 & 100 \\
\hline $\begin{array}{l}\text { The training encouraged me to start } \\
\text { teaching mathematics in preschool. } \\
\text { I feel I can incorporate the }\end{array}$ & 4 & 9.5 & 7 & 16.7 & 15 & 35.7 & 10 & 23.8 & 6 & 14.3 & 3.67 & 42 & 100 \\
\hline $\begin{array}{l}\text { "Senso-Math" program into the } \\
\text { preschool. }\end{array}$ & 3 & 6.4 & 2 & 4.3 & 11 & 23.4 & 17 & 36.2 & 14 & 29.8 & 3.57 & 47 & 100 \\
\hline $\begin{array}{l}\text { The training gave me professional } \\
\text { confidence. }\end{array}$ & & & & & 4 & 8.5 & 20 & 42.6 & 23 & 48.9 & 3.17 & 47 & 100 \\
\hline $\begin{array}{l}\text { The training encouraged me to } \\
\text { pursue my professional aspirations. }\end{array}$ & 3 & 6.7 & 2 & 4.4 & 13 & 28.9 & 16 & 35.6 & 11 & 24.4 & 2.96 & 45 & 100 \\
\hline $\begin{array}{l}\text { I am considering making } \\
\text { mathematics teaching my main } \\
\text { profession. }\end{array}$ & 1 & 2.2 & 3 & 6.5 & 19 & 41.3 & 15 & 32.6 & 8 & 17.4 & 2.45 & 46 & 100 \\
\hline
\end{tabular}

Note: Internal consistency was alpha equal to 0.63 .

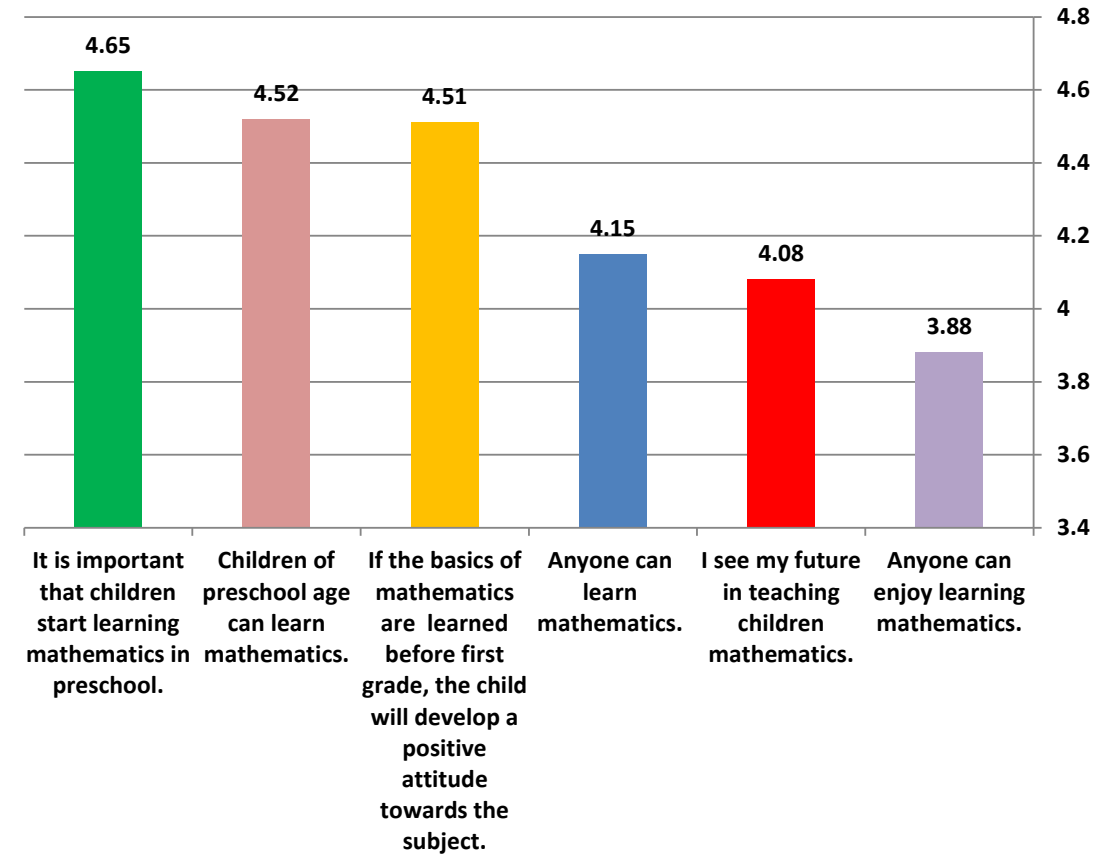

Figure 1. Attitudes of participants towards learning mathematics.

can do it at any age" (average 4.40), whereas the statement "I am considering making mathematics teaching my main profession” received the lowest score (average 2.45 ). It can be seen that the training encouraged the mediators to begin teaching mathematics in preschool (average 3.67), gave them the ability to integrate the "SensoMath” program into the preschool (average 3.57), and made them realize that teaching preschool requires readiness, knowledge and professional maturity (average 3.79). See also Figure 2.

\subsection{Self-Confidence in Mathematics}

Table 5 (see also Figure 3) indicates that, on one hand, the ratings to the statement "The training gave me 


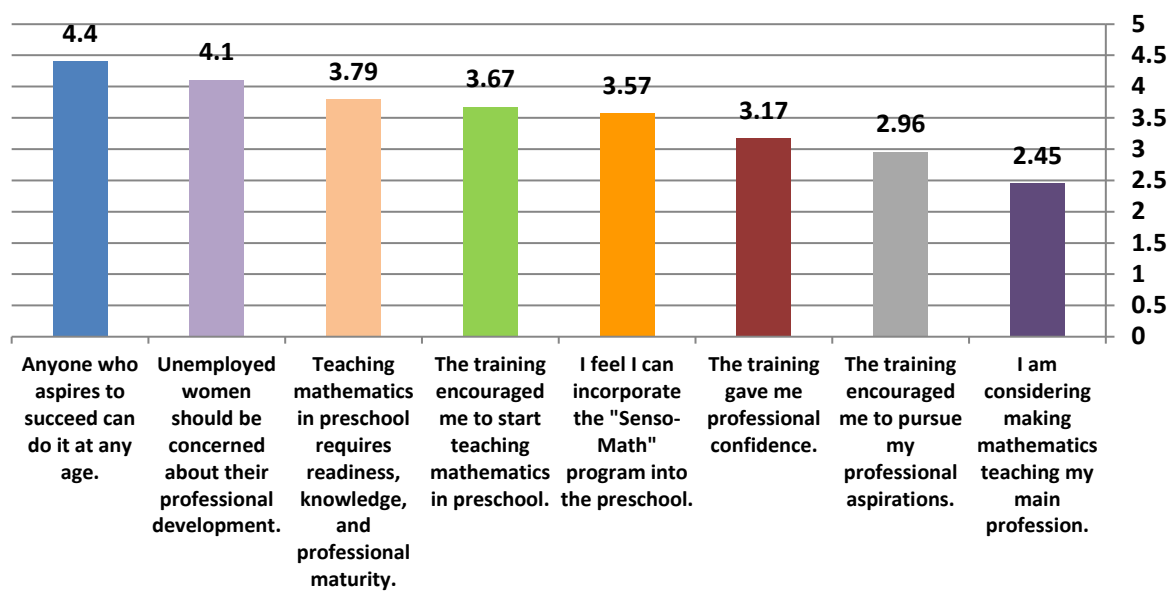

Figure 2. Professional development of participants.

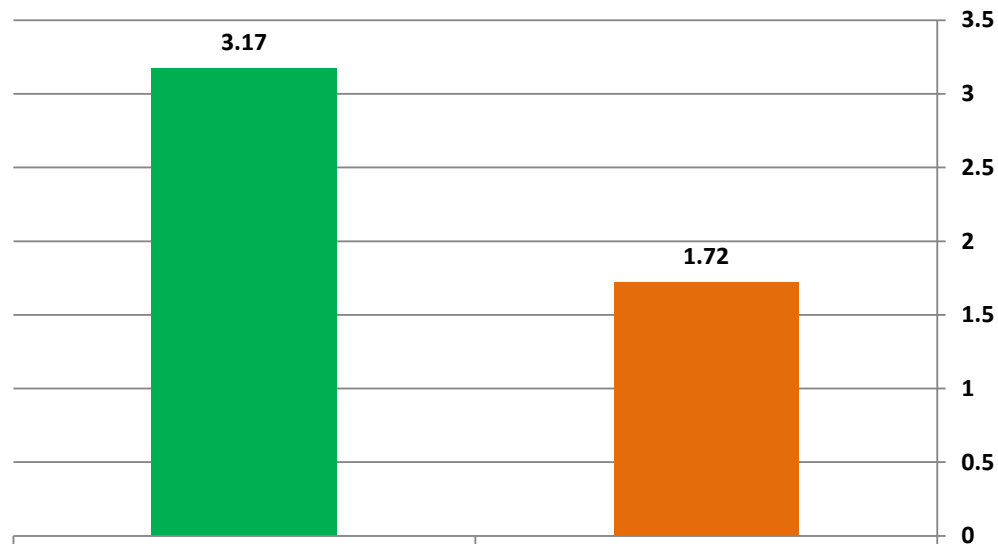

The training gave me confidence to teach Had I not participated in the "Senso-Math" mathematics. program, I would not have confidence to teach mathematics.

Figure 3. Self confidence in teaching mathematics.

Table 5. Self-confidence in teaching mathematics (Hypothesis No. 4).

\begin{tabular}{|c|c|c|c|c|c|c|c|c|c|c|c|c|c|}
\hline & \multicolumn{2}{|c|}{ Not at all } & \multicolumn{2}{|c|}{ Slightly } & \multicolumn{2}{|c|}{ Moderately } & \multicolumn{2}{|c|}{$\begin{array}{c}\text { To a large } \\
\text { extent }\end{array}$} & \multicolumn{2}{|c|}{$\begin{array}{c}\text { To a great } \\
\text { extent }\end{array}$} & \multirow{2}{*}{$\begin{array}{c}\text { Average } \\
\text { AV }\end{array}$} & \multicolumn{2}{|c|}{ Total } \\
\hline & $\mathrm{N}$ & $\%$ & $\mathrm{~N}$ & $\%$ & $\mathrm{~N}$ & $\%$ & $\mathrm{~N}$ & $\%$ & $\mathrm{~N}$ & $\%$ & & $\mathrm{~N}$ & $\%$ \\
\hline $\begin{array}{l}\text { The training gave me confidence } \\
\text { to teach mathematics. }\end{array}$ & 4 & 9.5 & 7 & 16.7 & 15 & 35.7 & 10 & 23.8 & 6 & 14.3 & 3.17 & 42 & 100 \\
\hline $\begin{array}{l}\text { Had I not participated in the } \\
\text { "Senso-Math" program, I would } \\
\text { not have confidence to teach } \\
\text { mathematics. }\end{array}$ & 29 & 63.0 & 5 & 10.9 & 9 & 19.6 & 2 & 4.3 & 1 & 2.2 & 1.72 & 46 & 100 \\
\hline
\end{tabular}

confidence to teach mathematics" shows that the participants believe that the training gave them more confidence, whereas the answers to “Had I not participated in the 'Senso-Math' program, I would not have confidence to teach mathematics" shows the opposite trend. However, interviews with the participants revealed that they had misunderstood the question because it was a negative statement and therefore rated it incorrectly.

\subsection{Program Evaluation}

Table 6 indicates that the participants believed that the "Senso-Math" program and materials had value inconsiderably improving their ability to teach mathematics in preschool. In general, it can be seen that most of the 
Table 6. Rating of the statements-evaluation of the program (Hypothesis No. 5).

\begin{tabular}{|c|c|c|c|c|c|c|c|c|c|c|c|c|c|}
\hline & \multicolumn{2}{|c|}{ Not at all } & \multicolumn{2}{|c|}{ Slightly } & \multicolumn{2}{|c|}{ Moderately } & \multicolumn{2}{|c|}{$\begin{array}{l}\text { To a large } \\
\text { extent }\end{array}$} & \multicolumn{2}{|c|}{ Very much } & \multirow{2}{*}{$\begin{array}{c}\text { Average } \\
\text { AV }\end{array}$} & \multicolumn{2}{|c|}{ Total } \\
\hline & $\mathrm{N}$ & $\%$ & $\mathrm{~N}$ & $\%$ & $\mathrm{~N}$ & $\%$ & $\mathrm{~N}$ & $\%$ & $\mathrm{~N}$ & $\%$ & & $\mathrm{~N}$ & $\%$ \\
\hline $\begin{array}{l}\text { The training gave me tools to } \\
\text { teach mathematics in preschool. }\end{array}$ & 1 & 2.2 & 1 & 2.2 & 7 & 15.2 & 18 & 39.1 & 19 & 41.3 & 4.15 & 46 & 100 \\
\hline $\begin{array}{l}\text { The training gave me tools to } \\
\text { facilitate mathematics in } \\
\text { preschool. }\end{array}$ & & & & & 11 & 25.0 & 14 & 31.8 & 19 & 43.2 & 4.18 & 44 & 100 \\
\hline $\begin{array}{l}\text { The "Senso-Math" activity pages } \\
\text { helped me in mathematical } \\
\text { facilitation in the preschool. }\end{array}$ & & & 1 & 2.3 & 9 & 20.9 & 14 & 32.6 & 19 & 44.2 & 4.19 & 43 & 100 \\
\hline $\begin{array}{l}\text { The "Senso-Math" facilitators' kit } \\
\text { helped me in mathematical } \\
\text { guidance in the preschool. }\end{array}$ & & & 1 & 2.7 & 4 & 10.8 & 15 & 40.5 & 17 & 45.9 & 4.30 & 37 & 100 \\
\hline $\begin{array}{l}\text { The course was conducted } \\
\text { professionally }\end{array}$ & 1 & 2.3 & 1 & 2.3 & 7 & 16.3 & 14 & 32.6 & 20 & 46.5 & 4.19 & 43 & 100 \\
\hline $\begin{array}{l}\text { I would recommend participating } \\
\text { in the "Senso-Math" program to a } \\
\text { friend. }\end{array}$ & 3 & 6.5 & 2 & 4.3 & 8 & 17.4 & 15 & 32.6 & 18 & 39.1 & 3.96 & 46 & 100 \\
\hline
\end{tabular}

Note: Internal consistency was alpha equal to 0.76 .

statements relating to the program and accompanying kit won high scores-above 4. Participants showed satisfaction with the tools that training gave them for teaching (average 4.15), the training for guiding mathematics in preschools (average 4.18), the teaching materials (average 4.19), and the facilitators kits (average 4.30). They felt that the training was conducted professionally (average 4.19). Most indicated that they would recommend the program to a friend.

\subsection{Differences between Participants}

Another area that the study investigated was the difference in attitudes towards teaching mathematics between various groups of participants (demographic, employment status, age, education, and number of children). Table 7 compares the attitudes towards teaching mathematics between the sectors studied. As can be seen, Caucasians and Druze expressed a more positive attitude than the Jewish Orthodox participants. Table 8 also indicates that the highest satisfaction from the program was expressed by the new immigrants from Caucasus (average 4.69), whereas the lowest satisfaction was expressed by the orthodox participants (average 3.36).

\subsection{Different Attitudes between Married and Unmarried Participants}

A second aspect of the study was to examine the differences in attitudes between married and unmarried participants (see Table 8). There was no significant statistical difference between married and unmarried women regarding their attitude toward the "Senso-Math" program or to the notion whether math should be taught in preschool (most agreed).

The contents presented in the table were determined based on factor analysis based on the statements detailed above.

Table 9 shows that there is no significant difference between attitudes towards the "Senso-Math" program among employed and unemployed women.

The statement regarding recommending the program to a friend was used to indicate the level of satisfaction from the program. Interestingly, Table 10 shows that the higher the education is, the lower the satisfaction from the program. Also, participants with higher education seemed to express less positive attitudes towards the program, and fewer believed in professional development than less educated women. The qualitative findings support, strengthen and clarify the quantitative findings.

This seems in interesting trend. Perhaps educated women are more critical in general, and this criticism is expressed by the attitudes they expressed towards the program.

\subsection{Summary of Results}

1) Participants were women: average 2.5 children; average 14 years education. 
Table 7. Differences in attitudes between participants from three different populations (Hypothesis No. 6).

\begin{tabular}{|c|c|c|c|c|c|}
\hline & & $\begin{array}{l}\text { New immigrants } \\
\text { from Caucasus } \\
\quad(\mathbf{n}=\mathbf{1 5})\end{array}$ & $\begin{array}{c}\text { Jewish Religious } \\
\text { Sector } \\
(\mathbf{n = 1 5})\end{array}$ & $\begin{array}{l}\text { Druze Sector } \\
\quad(\mathbf{n}=\mathbf{1 9})\end{array}$ & F-test \\
\hline $\begin{array}{l}\text { Degree of satisfaction from the program (I } \\
\text { would recommend participating in the } \\
\text { "Senso-Math" program to a friend). }\end{array}$ & $\begin{array}{c}\text { Average } \\
\text { sd }\end{array}$ & $\begin{array}{r}4.69 \\
(0.63)\end{array}$ & $\begin{array}{r}3.36 \\
(1.15)\end{array}$ & $\begin{array}{l}3.84 \\
(1.21)\end{array}$ & $5.45^{*}$ \\
\hline $\begin{array}{l}\text { Participants attitudes towards teaching } \\
\text { mathematics in preschool }\end{array}$ & $\begin{array}{c}\text { Average } \\
\text { sd }\end{array}$ & $\begin{array}{r}4.48 \\
(0.45)\end{array}$ & $\begin{array}{l}3.99 \\
(0.36)\end{array}$ & $\begin{array}{r}4.40 \\
(0.35)\end{array}$ & $7.11^{*}$ \\
\hline Professional development & $\begin{array}{c}\text { Average } \\
\text { sd }\end{array}$ & $\begin{array}{l}3.79 \\
(0.51)\end{array}$ & $\begin{array}{r}3.38 \\
(0.61)\end{array}$ & $\begin{array}{r}3.42 \\
(0.52)\end{array}$ & 2.65 \\
\hline Development of self-confidence & $\begin{array}{c}\text { Average } \\
\text { sd }\end{array}$ & $\begin{array}{l}2.58 \\
(1.02)\end{array}$ & $\begin{array}{l}2.27 \\
(0.94)\end{array}$ & $\begin{array}{l}2.39 \\
(0.83)\end{array}$ & 0.40 \\
\hline Program evaluation & $\begin{array}{c}\text { Average } \\
\text { sd }\end{array}$ & $\begin{array}{l}4.61 \\
(0.43)\end{array}$ & $\begin{array}{l}3.91 \\
(0.71)\end{array}$ & $\begin{array}{l}4.17 \\
(0.62)\end{array}$ & $4.95^{*}$ \\
\hline
\end{tabular}

Note: ${ }^{*} p<0.05$ - Significant difference between participants from different populations.

Table 8. Different attitudes between married and unmarried participants.

\begin{tabular}{|c|c|c|c|c|}
\hline \multirow{2}{*}{ Attitudes of participants: } & & \multicolumn{2}{|c|}{ Marital status } & \multirow[b]{2}{*}{ T-test } \\
\hline & & Married (n = 38) & Unmarried $(n=11)$ & \\
\hline \multirow{2}{*}{ Mathematical teaching in preschool } & Average & 4.28 & 4.40 & \multirow{2}{*}{-0.90} \\
\hline & sd & $(0.45)$ & $(0.36)$ & \\
\hline \multirow{2}{*}{ Development of professional confidence } & Average & 3.57 & 3.36 & \multirow{2}{*}{1.08} \\
\hline & sd & $(0.57)$ & $(0.56)$ & \\
\hline \multirow{2}{*}{ Developing self-confidence in mathematics } & Average & 2.54 & 1.85 & \multirow{2}{*}{2.21} \\
\hline & sd & $(0.86)$ & $(0.94)$ & \\
\hline \multirow{2}{*}{ Evaluation of the program } & Average & 4.15 & 4.43 & \multirow{2}{*}{-1.29} \\
\hline & sd & $(0.67)$ & $(0.62)$ & \\
\hline \multirow{2}{*}{$\begin{array}{l}\text { Would you recommend participating in the } \\
\text { "Senso-Math" program to a friend? }\end{array}$} & Average & 3.89 & 4.20 & \multirow{2}{*}{-0.72} \\
\hline & sd & $(1.16)$ & $(1.23)$ & \\
\hline
\end{tabular}

Table 9. Differences in attitudes between employed to unemployed participants.

\begin{tabular}{|c|c|c|c|c|}
\hline & & \multicolumn{2}{|c|}{ Occupational status } & \multirow[b]{2}{*}{ T-test } \\
\hline & & Employed $(n=37)$ & Unemployed $(\mathrm{n}=12)$ & \\
\hline \multirow{2}{*}{$\begin{array}{l}\text { Participantsattitudes towards teaching } \\
\text { mathematics in preschool }\end{array}$} & Average & 4.36 & 4.17 & \multirow{2}{*}{1.506} \\
\hline & sd & $(0.44)$ & $(0.40)$ & \\
\hline \multirow{2}{*}{ Professional development } & Average & 3.52 & 3.53 & \multirow{2}{*}{-0.086} \\
\hline & sd & $(0.51)$ & $(0.70)$ & \\
\hline \multirow{2}{*}{ Development of self-confidence } & Average & 2.29 & 2.68 & \multirow{2}{*}{-1.411} \\
\hline & sd & $(0.92)$ & $(0.85)$ & \\
\hline \multirow{2}{*}{ Program evaluation } & Average & 4.24 & 4.16 & \multirow{2}{*}{0.387} \\
\hline & sd & $(0.68)$ & $(0.62)$ & \\
\hline \multirow{2}{*}{$\begin{array}{l}\text { I would recommend participating in } \\
\text { "Senso-Math" program to a friend. }\end{array}$} & Average & 4.00 & 3.79 & \multirow{2}{*}{0.549} \\
\hline & sd & $(1.14)$ & $(1.25)$ & \\
\hline
\end{tabular}


Table 10. Correlation between number of children, years studied, and age with statements about satisfaction from the program and attitudes towards the program.

\begin{tabular}{cccccc} 
& $\begin{array}{c}\text { Would you recommend the Participants attitudes towards } \\
\text { "Senso-Math" program to a } \\
\text { friend? }\end{array}$ & $\begin{array}{c}\text { teaching mathematics in } \\
\text { preschool }\end{array}$ & $\begin{array}{c}\text { Professional } \\
\text { development }\end{array}$ & $\begin{array}{c}\text { Development of } \\
\text { Self-confidence }\end{array}$ & $\begin{array}{c}\text { Program } \\
\text { evaluation }\end{array}$ \\
\hline No of children & -0.26 & -0.13 & 0.03 & -0.05 & -0.29 \\
Age & -0.17 & -0.03 & -0.12 & -0.07 & $-0.36^{*}$ \\
Years studied & $-0.40^{* *}$ & $-0.31^{*}$ & $-0.47^{* *}$ & -0.13 & $-0.42^{* *}$ \\
\hline
\end{tabular}

Note: ${ }^{* *} p<0.05 ;{ }^{*} p<0.01$.

2) $66 \%$ of participants worked full time or part time before entering the "Senso-Math" program.

3) At completion of the program, $69 \%$ of participants worked. A year later, $75 \%$ worked (about a $9 \%$ increase).

4) A positive attitude towards the "Senso-Math" program was expressed by the participants (average score > 4). No correlation was found with marital or occupational status.

5) Results indicate that there was recognition of the need for children to study mathematics beginning inpreschool, and that children at this age are able to study mathematics.

6) Statements reflecting average self-confidence and responsible approach to professional development (“Unemployed women should worry about their professional development.”) received a high average score.

7) According to average scores, it cannot be unequivocally concluded that participating in the training will encourage women to try to fulfill professional ambitions and concentrate on teaching mathematics.

8) Participants rated the course and accompanying materials highly (over 4).

9) The new immigrants from the Caucasus and the Druze women expressed a more positive attitude and higher satisfaction than the group of Orthodox women.

10) The more educated the woman had, the more critical she was regarding the program and the less her satisfaction.

\section{Discussion}

Changes in Israel and abroad regarding teaching mathematics from preschool age and the need to prepare the child for the transition to school impose a heavy responsibility on the preschool teachers (Baroody, 2000). The "Senso-Math" program comes as an answer to this demand, expands the range of possibilities, and increases teaching resources by providing professional facilitators who are specially trained to teach mathematics in preschool using specially created exercises to allow children to experience math in a unique learning program.

This study shows that the "Senso-Math" program seems to be successful in this aspect, as can be seen from the fact that the majority of the participants in the program (75\%) had, a year later, been integrated into mathematics teaching in preschools.

Furthermore, according to the response, in preschools where facilitators were integrated, the mathematical learning environment became rich and diverse. The teacher benefited from a professional colleague (the facilitator) who came once or twice a week to the preschool, and who had the responsibility for teaching mathematics to the children. The teacher received training in teaching preschool math from the facilitators, and also learned through observation (modeling) of the facilitators' activities in the class. Facilitators reported that the teachers observed their activities with the children and repeated them during the week.

As one of the facilitators reported during her interview, her activity affected the preschool mathematical progression: "The teacher told me that since I had begun coming to the preschool, her attitude towards teaching mathematics changed. She told me that she is integrating daily mathematical activities into her program."

In addition, the introduction of facilitators in the preschools gave new prominence to mathematical instruction: The many tasks imposed upon the preschool teacher do not always allow her to devote sufficient time to teaching mathematics. Because the facilitators are engaged only in teaching mathematics, this aspect of preschool education becomes standard.

It was found that the facilitators who participated in the program recognized that children should and can learn mathematics in preschool. It was also found that the "Senso-Math" training contributed to their professional development and gave them confidence to facilitate mathematics teaching in preschool. Interviewees reported that 
the training and the accompanying materials were of a professional caliber and thus considerably contributed to their success in the program and, subsequently, to the preschool teachers and the children learners.

One of the conclusions drawn from this study was that the facilitators training program had a positive effect on the professional development of the participants. Teaching mathematics in preschool became a key area of interest to them that was intriguing and challenging. In addition, their addition became accepted as a positive contribution to the learning environment.

The introduction of facilitators into the preschool also impressed upon the teachers that teaching mathematics to preschool children requires professional understanding and training. For example one of the facilitators said in an interview: "In the beginning, the teacher objected to having me in her preschool and teaching mathematics. After several months, though, we were collaborating nicely. The teacher told me that now she realizes that teaching mathematics in the preschool is a very important area and that I, the facilitator, have received training that she lacks." In time, the facilitated mathematics teaching in the preschools was carried out in full cooperation between the teacher and the facilitator. The teacher observed the facilitators' methods, and used the activities to teach mathematics on the days when the facilitator was not present.

The structure and organization of the mathematical knowledge of developing preschoolers is affected by their learning experience (Clements, 2001). Complex activities lead to increased brain development.

The conclusion indicates that the "Senso-Math" program is the way to answer the current needs of an educational system that demands the introduction of mathematics education in preschool so as to prepare children for the transition to mathematics education in school.

\section{References}

Baroody, A. J. (2000). Does Mathematics Instruction for 3-to-5-Years Olds Really Make Sense? Young Children, 55 , 61-67.

Ben-Yehuda, M., \& Ilany, B. (2008). The Development of Mathematical Thinking in Young Children: Theory, Research and Practice in Training Teachers. Tel Aviv: MachonMofet Publications. (in Hebrew)

Boden, M. (1999). Piaget. Tel Aviv: Dvir Publishing Company. (in Hebrew)

Carpenter, T. P., Fenemma, E., Peterson, P. L., \& Carey, D. A. (1988). Teachers’ Pedagogical Content Knowledge of Students' Problem Solving in Elementary Arithmetic. Journal for Research in Mathematics Education, 19, 385-401. http://dx.doi.org/10.2307/749173

Charalambous, C. Y., Panaoura, A., \& Philippou, G. (2009). Using the History of Mathematics to Induce Changes in Pre-Service Teachers' Beliefs and Attitudes: Insights from Evaluating a Teacher Education Program. Educational Studies in Mathematics, 71, 161-180. http://dx.doi.org/10.1007/s10649-008-9170-0

Clements, D. H. (2001). Mathematics in the Preschool. Teaching Children Mathematics, 7, 270-275.

Clements, D. H., \& Sarama, J. (2006). The Young Child's Mathematical Mind. Parent \& Child, 10, 30-37.

Cobb, P. (1996). Accounting for Mathematical Learning in Social Context of the Classroom. An Invited Address Presented at ICME 8, Seville: ICME.

Fiske, S. T., \& Taylor, S. E. (2008). Social Cognition: From Brains to Culture. Boston, MA: McGraw-Hill Higher Education.

Guo, Y., Justice, L. M., Sawyer, B., \& Tompkins, V. (2011). Exploring Factors Related to Preschool Teachers’ Self-Efficacy, Teaching and Teacher Education. International Journal of Research and Studies, 27, 961-968.

Israel Ministry of Education (2009). Curriculum for the Education of Mathematics in Early Childhood (Core Mathematics Program). The Department for the Development of School Curricula, Israel Ministry of Education.

Kilpatrick, J., Swafford, J., \& Findell, B. (2001). Adding It Up: Helping Children Learn Mathematics. Mathematics Learning Study Committee, Center for Education, Division of Behavioral and Social Sciences and Education. Washington, DC: National Academy Press.

McLeod, D. B. (1992). Research on Affect in Mathematics Education: A Reconceptualization. In D. A. Grouws (Ed.), Handbook of Research on Mathematics Learning and Teaching (pp. 575-596). New York: Macmillan.

National Association for the Education of Young Children (NAEYC) and the National Council of Teachers of Mathematics (NCTM) (2002). Early Childhood Mathematics: Promoting Good Beginnings. A Joint Position Statement.

National Council of Teachers of Mathematics (NCTM) (2000). Principles and Standards for School Mathematics. Reston, VA: NCTM.

Philipp, R. A. (2007). Mathematics Teachers’ Beliefs and Affect. In F. K. Lester (Ed.), Second Handbook of Research on Mathematics Teaching and Learning (pp. 257-315). Charlotte, NC: Information Age Publishing. 
Philippou, G. N., \& Christou, C. (1998). The Effects of a Preparatory Mathematics Program in Changing Prospective Teachers’ Attitudes towards Mathematics. Educational Studies in Mathematics, 35, 189-206. http://dx.doi.org/10.1023/A:1003030211453

Pimm, D. (1987). Speaking Mathematically: Communication in Mathematics Classrooms. London: Routledge.

Plucker, J. (1996). Secondary Science and Mathematics Teachers and Gender Equity: Attitudes and Attempted Interventions. Journal of Research in Science Teaching, 33, 737-751. http://dx.doi.org/10.1002/(SICI)1098-2736(199609)33:7<737::AID-TEA3>3.0.CO;2-O

Tirosh, D., \& Graeber, O. A. (1990). Evoking Cognitive Conflict to Explore Pre-service Teachers' Thinking. Journal for Research in Mathematics Education, 21, 98-108. http://dx.doi.org/10.2307/749137

Vygotsky, L. S. (1962). Thought and Language. Cambridge, MA: MIT Press. http://dx.doi.org/10.1037/11193-000 
Scientific Research Publishing (SCIRP) is one of the largest Open Access journal publishers. It is currently publishing more than 200 open access, online, peer-reviewed journals covering a wide range of academic disciplines. SCIRP serves the worldwide academic communities and contributes to the progress and application of science with its publication.

Other selected journals from SCIRP are listed as below. Submit your manuscript to us via either submit@scirp.org or Online Submission Portal.
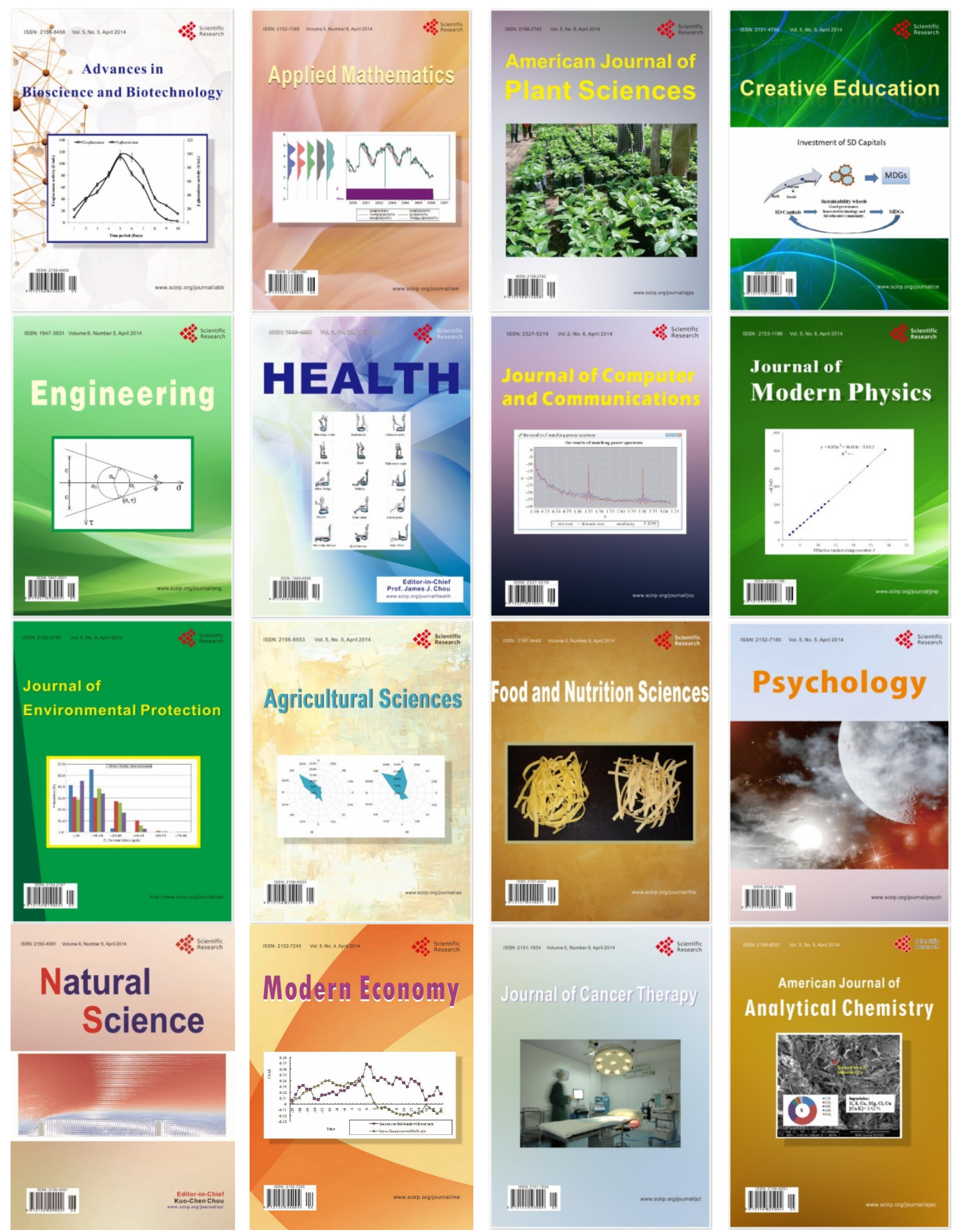